\title{
Antioxidant status, and blood zinc and copper concentrations in dogs with uncomplicated babesiosis due to Babesia canis infections
}

\author{
Oliwier Teodorowski ${ }^{1}$, Stanisław Winiarczyk ${ }^{2}$, Duygu Tarhan ${ }^{3}$, Banu Dokuzeylül ${ }^{4}$, \\ Alev Meltem Ercan ${ }^{3}$, Mehmet Erman Or ${ }^{4}$, Marta Staniec ${ }^{2 \bowtie}$, Łukasz Adaszek ${ }^{2}$ \\ 1“"Teodorowscy" Veterinary Clinic, 43-190 Mikołów, Poland \\ ${ }^{2}$ Department of Epizootiology and Clinic of Infectious Diseases, Faculty of Veterinary Medicine, \\ University of Life Sciences in Lublin, 20-612 Lublin, Poland \\ ${ }^{3}$ Department of Biophysics, Cerrahpasa Medical Faculty, Istanbul University-Cerrahpasa, Fatih, 34098, Istanbul, Turkey \\ ${ }^{4}$ Department of Internal Medicine, Faculty of Veterinary Medicine, Istanbul University-Cerrahpasa, \\ 34320 Avcilar Campus, Avcilar, Istanbul, Turkey \\ marta.staniec@up.lublin.pl
}

Received: December 2, $2020 \quad$ Accepted: May 18, 2021

\begin{abstract}
Introduction: The aim of the study was to demonstrate a link between uncomplicated Babesia canis infection in dogs and blood concentrations of zinc and copper and erythrocytic antioxidant defence - activities of glutathione (GSH), superoxide dismutase (SOD) and catalase (CAT). Material and Methods: The study was based on 15 naturally occurring cases of canine babesiosis with anorexia, pyrexia, depression, pale mucous membrane, splenomegaly and dark red urine. Microscopic examination of Giemsa-stained peripheral blood smears and the results of PCR confirmed B. canis infection. Seven apparently healthy dogs brought in for either a check-up or vaccination were used for comparison. Results: The levels of the erythrocytic antioxidant enzymes - SOD and CAT - were significantly higher in the infected dogs than in cytologically negative dogs. The levels of blood micronutrients were significantly lower in the infected dogs $(0.478 \mu \mathrm{g}$ of zinc per $\mathrm{mL} v s 1.241 \mu \mathrm{g} / \mathrm{mL}$ and $0.722 \mu \mathrm{g}$ of copper per mL vs $1.392 \mu \mathrm{g} / \mathrm{mL}$ ). Conclusion: Oxidative stress can be posited as one of the mechanisms leading to anaemia in dogs with babesiosis, and therefore antioxidant biomarker and copper and zinc concentrations could be used as indicators of disease severity and prognostic markers.
\end{abstract}

Keywords: Babesia canis, copper, zinc, superoxide dismutase, catalase.

\section{Introduction}

Canine babesiosis is a common and clinically significant tick-borne disease caused by haematozoan parasites of the genus Babesia (4). Two morphologically distinct forms of the erythrocytic stage in the canine host were recognised - the larger form $(3-5 \mu \mathrm{m})$ B. canis and the smaller $(1-3 \mu \mathrm{m})$ B. gibsoni (3). Cross-immunity, serological testing, vector specificity and molecular phylogeny were used to reclassify Babesia canis into three separate species (B. canis, B. rossi and B. vogeli) $(10,33)$. Within the small piroplasms, three distinct species are recognised as causing disease in dogs: B. gibsoni, B. conradae, and B. vulpes (B. microti-like piroplasm, Theileria annae) (17, 18). Recently, Mierzejewska et al. (21) detected Babesia vulpes in foxes in Poland - this is a new species, which can cause infestations in the country's dogs.

Our earlier study described the clinical course of babesiosis in dogs from areas of eastern Poland and selected aberrant haematological and biochemical parameters of the serum of dogs infected with this disease (4). The clinical picture of infection with $B$. canis is diverse, ranging from hyper-acute through acute to chronic disease (4).

Babesia protozoa invade the erythrocytes of the host animals, and the destruction of the parasitised erythrocytes is a common consequence of infection, leading to anaemia (4). The severity of the anaemia is not always proportional to the degree of parasitaemia (8). The quantity of destroyed erythrocytes is usually much higher than the degree of parasitaemia, suggesting 
that non-parasitised erythrocytes may also be damaged (11). Some of the proposed mechanisms responsible for this phenomenon are sequestration of infected erythrocytes in microcirculation, decreased erythrocyte deformability, and haemodilution and destruction of red blood cells due to the effects of oxidative stress $(11,23$, $27,28,29)$. Free radicals and other reactive oxygen species (ROS) have been implicated as playing an important role in tissue damage in a variety of pathological processes (8). Overproduction of ROS in diverse pathological conditions leads to oxidative damage to macromolecules, which results in more intensive lipid peroxidation and DNA strand breaks (16, 22). To counteract the oxidative damage caused by ROS generated during infections, a multi-layered defence system is generated, including DNA repair systems, scavenging substrates and the antioxidant enzyme system $(7,11)$. Indirect loss of essential body nutrients caused by accelerated metabolism or consumption has been speculated to occur during the course of infectious diseases (8). The plasma zinc value appears susceptible to shock and fever (8). Zinc deficiency has also been reported as enhancing oxidative damage to proteins, lipids and DNA in rat tissues (22). Micronutrients such as zinc and copper are also essential components of the body's antioxidant defence and play an important role in the prevention of free radical-induced damage to tissues required for the maintenance of health and production (15). Zinc and copper are utilised for the synthesis of the important antioxidant enzyme, $\mathrm{Cu}-\mathrm{Zn}$ superoxide dismutase (SOD), which catalyses the conversion of the superoxide radical to the less oxidising $\mathrm{H}_{2} \mathrm{O}_{2}$.

The aim of the study was to demonstrate a link between uncomplicated $B$. canis infection in dogs and blood concentrations of zinc and copper and erythrocytic antioxidant defence.

\section{Material and Methods}

Animals used in the study. Fifteen dogs with babesiosis (group 1) aged 2-7 years (mean 4.13) and seven healthy dogs (group 2) aged 1-5 years (mean 3.29) were studied prospectively between March and June 2020. The 15 dogs in group 1 showed symptoms of uncomplicated babesiosis, which appeared 2-3 days before their admission to the clinic. The seven healthy dogs in group 2 were admitted to the clinic for a routine check-up. They did not show any clinical abnormalities. Blood was collected from all dogs for haematological, biochemical and molecular analyses.

Blood analyses. The samples were collected in a routine way, before any treatment was administered. Blood was taken from the cephalic vein into tubes with ethylenediaminetetraacetic acid (EDTA) for haematological and PCR evaluation, and into plain tubes for biochemical evaluation. Thin blood smears were stained by the Giemsa method and examined for parasites.
The analyses of $\mathrm{Zn}$ and $\mathrm{Cu}$ trace elements levels were carried out using inductively coupled plasmaoptical emission spectrometry (ICP-OES; iCAP 6000 series, Thermo Fisher Scientific, Waltham, MA, USA). Each measurement was performed three times and averages were used for the analysis. In the study, the appropriate wavelengths of the $\mathrm{Zn}$ and $\mathrm{Cu}$ elements $(206.200 \mathrm{~nm}$ and $324.754 \mathrm{~nm}$, respectively) were used for analysis in the ICP-OES device. Stock solutions for $\mathrm{Zn}$ and $\mathrm{Cu}$ trace elements were prepared from standard solutions (Chem-Lab NV, Zedelgem, Belgium) and distilled water was used as a blank solution. Calibration graphs were obtained from the ICP-OES device using blank and standard solutions and the concentration measurements of $\mathrm{Zn}$ and $\mathrm{Cu}$ trace elements were carried out according to the graphs. The blood plasma samples were diluted with distilled water. The standard solutions were measured again for system control after every five sample analyses. The concentration levels of $\mathrm{Zn}$ and $\mathrm{Cu}$ were expressed as $\mu \mathrm{g} / \mathrm{mL}$.

The activities of glutathione (GSH), SOD and catalase (CAT) were determined in whole blood in tubes with lithium heparin. Superoxide dismutase activity in the erythrocytes was determined using a commercial Ransod diagnostics kit (Randox Laboratories, Crumlin, UK), according to the manufacturer's instructions, and CAT activity was determined according to Aebi (5). The plasma content of GSH was determined according to the methods described by Bartosz (6).

Molecular examination. DNA for PCR was extracted from EDTA-anticoagulated whole blood using the QIAamp DNA Mini Kit (Qiagen, Hilden, Germany), according to the manufacturer's instructions. The amplification of $B$. canis DNA was performed using the forward primer BAB GF2 (5'-GTC TTG TAA TTG GAA TGA TGG-3') and the reverse primer BAB GR2 (5'-CCA AAG ACT TTG ATT TCT CTC-3'), which duplicate a 559-bp region of the $18 \mathrm{~S}$ rRNA gene of B. canis (2).

The real-time PCR reaction for all the isolated DNA samples was carried out using the Rotor-Gene RG6000 real-time DNA amplification system (Corbett Research, Mortlake, NSW, Australia) with SYBR Green 1 dye in thin-walled test-tubes with a capacity of $100 \mu \mathrm{L}$. A DyNAmo HS SYBR Green qPCR Kit (Finnzymes, Espoo, Finland ) was used to conduct the high-specificity reaction.

The reaction mixture, with a capacity of $20 \mu \mathrm{L}$, consisted of the following components: $2 \mu \mathrm{L}$ of the DNA matrix, $7.2 \mu \mathrm{L}$ of water, $0.4 \mu \mathrm{L}$ of each of the GF2 and GR2 primers (final concentration of $50 \mathrm{pM}$ ), $10 \mu \mathrm{L}$ of Master Mix containing a hot start version of the modified Thermus brockianus (Tbr) polymerase, buffer for the Tbr polymerase, deoxynucleotide triphosphate, $\mathrm{MgCl}_{2}$, and the intercalating SYBR Green 1 dye.

The optimised real-time PCR reaction included 50 cycles, each comprising three stages: denaturation at $92^{\circ} \mathrm{C}$ for $60 \mathrm{~s}$, annealing at $52^{\circ} \mathrm{C}$ for $60 \mathrm{~s}$, and extension at $72^{\circ} \mathrm{C}$ for $90 \mathrm{~s}(3)$. 
The PCR products were then purified using QIAquick spin columns (Qiagen), eluted in $50 \mu \mathrm{L}$ of Tris $10 \mathrm{mM}, \mathrm{pH} 7.6$, and sequenced at the Research Institute of the Polish Academy of Sciences, in Warsaw. DNA sequences were assembled and edited using SeqMan (Lasergene, DNAStar, Madison, WI, USA), and ClustalV alignments were generated to the published B. canis canis 18S rRNA gene (GenBank accession numbers EU622792 and EU622793).

Statistical analysis. The Mann-Whitney rank test was used to demonstrate the differences in $\mathrm{Zn}$ and $\mathrm{Cu}$ concentrations between the groups and between other haematological and biochemical parameters. Changes were considered statistically significant at $\mathrm{P}<0.05$. Statistica 10.0 PL software (StatSoft, now Tibco, Palo Alto, CA, USA) was used for the calculations.

\section{Results}

All dogs in group 1 were apathetic. They also showed signs of anorexia, pyrexia, depression, and splenomegaly and had pale mucous membranes and dark red urine. The dogs in group 1 were injected subcutaneously with imidocarb dipropionate solution (Imizol; Schering Plough Animal Health, now MSD Animal Health, Kenilworth, NJ, USA), in a dosage of $5 \mathrm{mg} / \mathrm{kg}$ b.w., which resulted in recovery in all cases.

None of the dogs in group 2 showed any clinical signs of the disease. They were clinically healthy for the whole period of the study.

The results of haematological analysis showed some abnormally low levels in group $1 \mathrm{dogs}$ but none in group 2 animals. A drop in haematocrit below 37\% (the lower limit of normal) was found in every dog in group 1. A decrease of erythrocytes below $5.5 \times 10^{12}$ (the lower limit of normal) was noted in 9 of the dogs with uncomplicated babesiosis. Leukopaenia (white blood cell count $<6 \times 10^{9}$ ) occurred in 6 sick dogs, while thrombocytopenia (platelet count $<200 \times 10^{9}$ ) was reported in all afflicted dogs (Table 1).

Copper concentration was below normal in 14 out of the 15 dogs in group 1 (mean value $0.722 \mu \mathrm{g} / \mathrm{mL}$ ) and was statistically significantly lower $(\mathrm{P}=0.000247)$ than in the dogs in group 2, which all showed normal blood copper concentrations (mean value $1.392 \mu \mathrm{g} / \mathrm{mL}$ ). The majority of the dogs in group $1(13 / 15)$ had zinc blood concentrations below the lower limit of normal (mean value $0.478 \mu \mathrm{g} / \mathrm{mL}$ ), whereas all the dogs in group 2 had normal values for this parameter (mean value $1.241 \mu \mathrm{g} / \mathrm{mL}$ ). The differences were statistically significant $(\mathrm{P}=0.000323)$ (Tables 2 and 3).

Erythrocytic SOD activity in B. canis-infected dogs was significantly higher $(\mathrm{P}=0.000421)$ than in the control dogs. The mean value of SOD in group 1 was $36.78 \mathrm{U} / \mathrm{mL}$, while in group 2 it was $31.08 \mathrm{U} / \mathrm{mL}$.
Table 1. Results of haematological examinations of dogs from group 1 (dogs with babesiosis) and 2 (healthy dogs)

\begin{tabular}{|c|c|c|c|c|c|}
\hline Group & Dog & $\begin{array}{c}\text { WBC } \\
\left(\times 10^{9}\right) \\
\end{array}$ & $\begin{array}{c}\text { RBC } \\
\left(\times 10^{12}\right) \\
\end{array}$ & $\begin{array}{c}\mathrm{Ht} \\
(\%)\end{array}$ & $\begin{array}{c}\text { PLT } \\
\left(\times 10^{9}\right) \\
\end{array}$ \\
\hline \multirow{15}{*}{1} & 1 & 6.8 & 6.76 & 38.7 & 43 \\
\hline & 2 & 5.0 & 7.29 & 45.0 & 28 \\
\hline & 3 & 6.9 & 6.20 & 38.4 & 24 \\
\hline & 4 & 4.3 & 6.54 & 40.5 & 27 \\
\hline & 5 & 6.2 & 5.39 & 32.0 & 30 \\
\hline & 6 & 7.8 & 5.98 & 34.4 & 65 \\
\hline & 7 & 10.3 & 6.40 & 39.2 & 35 \\
\hline & 8 & 6.8 & 3.78 & 24.8 & 19 \\
\hline & 9 & 6.1 & 3.97 & 25.2 & 31 \\
\hline & 10 & 9.3 & 4.30 & 25.6 & 39 \\
\hline & 11 & 4.1 & 4.73 & 29.7 & 16 \\
\hline & 12 & 7.7 & 5.08 & 32.4 & 48 \\
\hline & 13 & 5.6 & 4.75 & 29.7 & 28 \\
\hline & 14 & 4.8 & 5.07 & 31.7 & 29 \\
\hline & 15 & 5.5 & 5.11 & 36.2 & 46 \\
\hline \multirow{8}{*}{2} & 16 & 10.4 & 6.40 & 42.1 & 231 \\
\hline & 17 & 9.8 & 6.54 & 39.9 & 379 \\
\hline & 18 & 8.9 & 6.86 & 44.4 & 224 \\
\hline & 19 & 8.8 & 7.12 & 49.6 & 443 \\
\hline & 20 & 6.8 & 6.54 & 39.9 & 379 \\
\hline & 21 & 9.9 & 6.16 & 42.1 & 220 \\
\hline & 22 & 8.4 & 6.58 & 42.3 & 328 \\
\hline & Range & $6.0-17.0$ & $5.50-8.50$ & $37.0-55.0$ & $200-500$ \\
\hline
\end{tabular}

WBC - white blood cells; RBC - red blood cells; Ht - haematocrit; PLT - platelets

Table 2. $\mathrm{Cu}$ and $\mathrm{Zn}$ concentrations in blood of dogs from groups 1 (dogs with babesiosis) and 2 (healthy dogs)

\begin{tabular}{|c|c|c|c|}
\hline Dog & $\mathrm{Cu} 1.350 \mu \mathrm{g} / \mathrm{mL}$ & $\mathrm{Zn} 1.485 \mu \mathrm{g} / \mathrm{mL}$ & Group \\
\hline 1 & 0.788 & 0.400 & 1 \\
\hline 2 & 0.713 & 0.463 & 1 \\
\hline 3 & 0.578 & 0.249 & 1 \\
\hline 4 & 0.650 & 0.379 & 1 \\
\hline 5 & 0.818 & 0.455 & 1 \\
\hline 6 & 0.658 & 0.463 & 1 \\
\hline 7 & 0.524 & 0.404 & 1 \\
\hline 8 & 0.823 & 0.905 & 1 \\
\hline 9 & 0.724 & 0.610 & 1 \\
\hline 10 & 0.662 & 0.466 & 1 \\
\hline 11 & 0.684 & 0.383 & 1 \\
\hline 12 & 0.790 & 0.380 & 1 \\
\hline 13 & 0.812 & 0.622 & 1 \\
\hline 14 & 0.792 & 0.410 & 1 \\
\hline 15 & 0.816 & 0.587 & 1 \\
\hline 16 & 0.894 & 1.412 & 2 \\
\hline 17 & 1.120 & 1.184 & 2 \\
\hline 18 & 1.830 & 0.923 & 2 \\
\hline 19 & 0.993 & 1.340 & 2 \\
\hline 20 & 1.751 & 0.882 & 2 \\
\hline 21 & 1.344 & 1.612 & 2 \\
\hline 22 & 1.812 & 1.332 & 2 \\
\hline
\end{tabular}


Table 3. CAT, SOD and GSH activity in dogs of groups 1 (dogs with babesiosis) and 2 (healthy dogs)

\begin{tabular}{ccccc}
\hline Dog & CAT $(\mathrm{U} / \mathrm{mL})$ & SOD $(\mathrm{U} / \mathrm{mL})$ & GSH $(\mathrm{U} / \mathrm{mL})$ & Group \\
\hline 1 & 9.6966 & 38.41 & 3.1 & 1 \\
2 & 6.2483 & 38.70 & 1.5 & 1 \\
3 & 7.9172 & 36.34 & 4.5 & 1 \\
4 & 6.2483 & 33.52 & 3.7 & 1 \\
5 & 2.6483 & 36.88 & 2.4 & 1 \\
6 & 4.4690 & 38.16 & 3.4 & 1 \\
7 & 2.4000 & 36.88 & 4.9 & 1 \\
8 & 4.8828 & 34.98 & 3.6 & 1 \\
9 & 3.8207 & 34.75 & 3.9 & 1 \\
10 & 3.4414 & 34.25 & 5.9 & 1 \\
11 & 4.2631 & 36.21 & 2.3 & 1 \\
12 & 3.9343 & 38.18 & 3.1 & 1 \\
13 & 4.9251 & 39.46 & 2.3 & 1 \\
14 & 3.2887 & 39.14 & 2.1 & 1 \\
15 & 6.1181 & 35.82 & 3.2 & 1 \\
16 & 2.1241 & 34.57 & 3.0 & 2 \\
17 & 0.8552 & 28.69 & 2.3 & 2 \\
18 & 1.0000 & 31.51 & 3.6 & 2 \\
19 & 0.6621 & 30.34 & 2.7 & 2 \\
20 & 0.7448 & 31.72 & 2.2 & 2 \\
21 & 1.8342 & 29.23 & 2.9 & 2 \\
22 & 1.5261 & 31.51 & 4.4 & 2 \\
\hline
\end{tabular}

CAT - catalase; SOD - superoxide dismutase; GSH - glutathione

The CAT activity in the erythrocytes of the dogs infected with $B$. canis was also higher than in those of the healthy dogs. The mean value in group 1 was $4.9535 \mathrm{U} / \mathrm{mL}$ and in group 2 was $1.2495 \mathrm{U} / \mathrm{mL}$. The differences were statistically significant $(\mathrm{P}=0.000246)$.

There was no significant difference $(\mathrm{P}=0.458446)$ in the GSH activity between the infected and control dogs. The mean value of this parameter in the blood of dogs with babesiosis was $3.26 \mathrm{U} / \mathrm{mL}$, whereas in that of healthy dogs it was $3.01 \mathrm{U} / \mathrm{mL}$.

B. canis DNA was detected in the blood samples taken from all 15 infected dogs examined with the real-time PCR. The products were visualised with the electrophoresis method in agarose gel. Their size compared to the mass standard was about $559 \mathrm{bp}$ (Fig. 1). The $\mathrm{Ct}$ values read from the amplification curve fluctuated around 17 cycles for all the examined samples (Fig. 2). The melting temperature was between $78^{\circ} \mathrm{C}$ and $81^{\circ} \mathrm{C}$.
Based on the similarities between sequences of the 18S RNA gene fragment, five of the isolated Babesia protozoa were classified as the EU622792 18S RNA-A strain and the remaining nine as the EU622793 18S RNA-B strain.

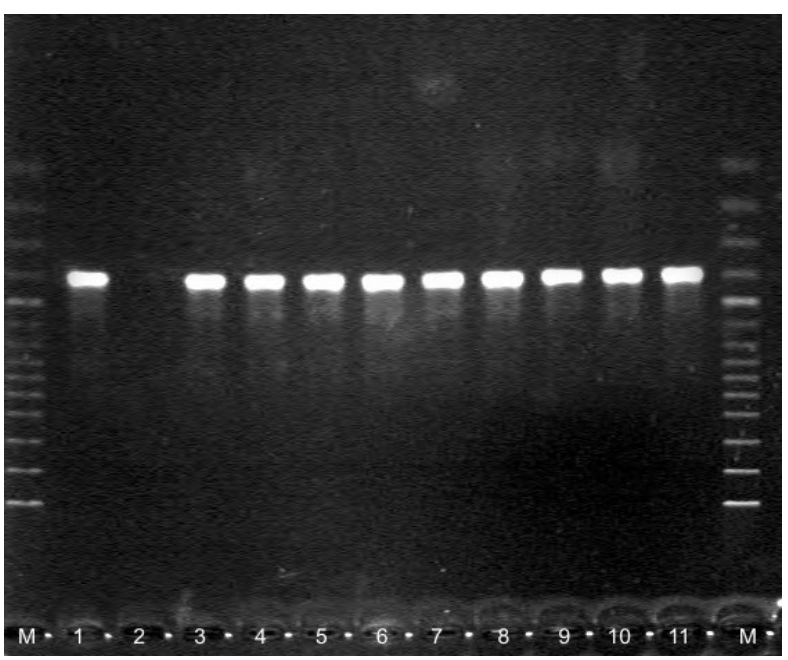

Fig. 1. PCR amplification of a partial sequence of $B$. canis 18S RNA gene (product size 559 bp)

$\mathrm{M}$ - 100bp molecular weight marker; 1 - positive control; 2 - negative control; 3-11 - studied samples from dogs with babesiosis

\section{Discussion}

The aim of this study was to evaluate the possible changes in three antioxidant biomarkers (SOD, CAT, and $\mathrm{GSH}$ ), as well as in $\mathrm{Cu}$ and $\mathrm{Zn}$ concentrations in dogs infected with babesiosis. The literature data on this subject in dogs are very scarce, and can be found in only two studies $(8,11)$. Dogs naturally infected with $B$. canis and investigated by Crnogaj et al. (12) presented serum malondialdehyde levels which confirmed the presence of oxidative stress. Oxidative stress seems to be one of the mechanisms leading to erythrocyte deformation in dogs with babesiosis; therefore, antioxidant biomarkers, as well as copper and zinc, could be used as indicators of anaemia severity.

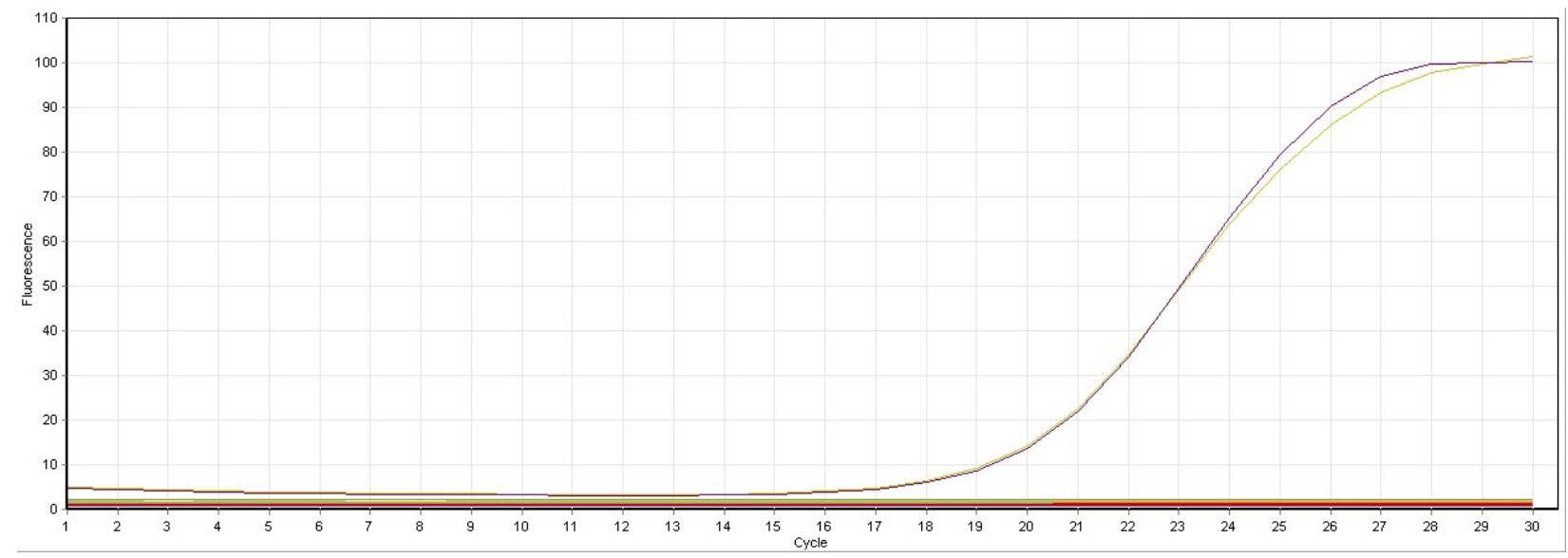

Fig. 2. Real-time PCR amplification curve. $\mathrm{Ct}$ values fluctuated around 17 cycles for all the examined samples 
Our own studies revealed significantly lower concentrations of $\mathrm{Zn}$ and $\mathrm{Cu}$ in the blood of dogs with babesiosis compared to the control group. In anaemic cattle infected with $B$. bigemina, decreased serum levels of copper and zinc were observed. It can be assumed that the decreased levels of trace elements represent their coordinated antioxidant role along with antioxidant enzyme activities during the infection (14). Both elements play a role in the synthesis of an antioxidant enzyme, $\mathrm{Cu}-\mathrm{Zn} \mathrm{SOD}$, so their reduced concentrations in infected dogs may be caused by their increased use. On the other hand, in the course of various infectious diseases the levels of these elements in infected dogs are lower (especially in the acute phase of the infection) as a result of increased metabolism and reduced supply of $\mathrm{Cu}$ and $\mathrm{Zn}$ with food, due to anorexia associated with stress and fever $(9,31)$. Such mechanisms were observed, for instance, in cattle with theileriosis $(19,20)$ and in dogs with babesiosis caused by $B$. gibsoni invasion (8).

Our studies demonstrated that in dogs with babesiosis, the SOD and CAT activity was higher than in healthy dogs. These findings conflict with the results presented by Crnogaj et al. (11), who observed decreased activity of these antioxidant biomarkers in dogs infected with $B$. canis. Similarly, in sheep with babesiosis (14), in cattle with theileriosis (26) and in people suffering from malaria (13), reductions in SOD, CAT and GSH activity were reported. These enzyme activity profiles may be determined by the disease stage. Our study involved dogs with an early, uncomplicated form of babesiosis. The study by Crnogaj et al. (11) demonstrated that SOD, CAT and GSH showed a significantly lower activity in dogs with multiple organ dysfunction syndrome (MODS) than in those with uncomplicated babesiosis. The different stages of the disease might explain the discrepancy between the results.

Our observations are confirmed by the results of studies by Otsuka et al. (25) and Chaudhuri et al. (8). They demonstrated increased activity of SOD and CAT in dogs infected by B. gibsoni, which is consistent with our findings. This may be a defence mechanism, where the organism attempts to prevent the oxidative damage of cells in the course of babesiosis. SOD, CAT and GSH are the major enzymes present in red blood cells to counteract the toxic effects of ROS such as superoxide radicals and hydrogen peroxides (8). The increased activity of SOD and CAT may also be due to a higher number of reticulocytes in the blood of infected animals produced by the bone marrow in response to the destruction of mature erythrocytes by the protozoa $(25$, 30,32 ). In addition, CAT is responsible for the breakdown of $\mathrm{H}_{2} \mathrm{O}_{2}$, an important ROS produced during metabolism, so increased CAT activity might correlate with the generation of $\mathrm{H}_{2} \mathrm{O}_{2}$ in $\mathrm{B}$. canis-infected dogs.

We did not observe any correlation between the type of parasite strain causing the infection and the SOD, CAT, and GSH in the infected dogs, as happens with other clinical parameters $(1,4)$. Further studies in this respect are necessary, conducted on a larger group of animals.

In conclusion, the clinical study demonstrated that in dogs with uncomplicated early babesiosis, contrary to the biomarker picture in animals with advanced disease associated with MODS, the SOD and CAT activity were increased, while concentrations of $\mathrm{Cu}$ and $\mathrm{Zn}$ were reduced. Considering the strong negative correlation between the activity of antioxidants (SOD, CAT and GSH) in MODS cases and lethal outcome, it appears that the increased activity of SOD and CAT demonstrated in the study is a favourable prognostic, indicative of the uncomplicated form of the disease.

Conflict of Interests Statement: The authors declare that there is no conflict of interests regarding the publication of this article.

Financial Disclosure Statement: The source of funding of research and the article was the authors' own resources.

Animal Rights Statement: None required.

\section{References}

1. Adaszek Ł., Górna M., Winiarczyk S.: Electrolyte level and blood $\mathrm{pH}$ in dogs infected by various 18 S RNA strains of Babaesia canis canis on the early stage of babesiosis. Berl Munch Tierarztl Wochenschr 2012, 125, 45-51, doi: 10.2376/0005-9366-125-45.

2. Adaszek Ł., Winiarczyk S.: Molecular characterization of Babesia canis canis isolates from naturally infected dogs in Poland. Vet Parasitol 2008, 152, 235-241, doi: 10.1016/j.vetpar.2007.12.024.

3. Adaszek Ł., Winiarczyk S.: Application of the SYBR Green realtime HRM PCR technique in the differentiation of the Babesia canis canis protozoa isolated in the areas of eastern Poland. Parasitol Res 2010, 106, 1253-1256, doi: 10.1007/s00436-0101784-3.

4. Adaszek Ł., Winiarczyk S., Skrzypczak M.: The clinical course of babesiosis in 76 dogs infected with protozoan parasites Babesia canis canis. Pol J Vet Sci 2009, 12, 81-87.

5. Aebi H.: Catalase in vitro. Meth Enzymol 1984, 105, 121-126, doi: 10.1016/S0076-6879(84)05016-3.

6. Bartosz G.: Druga twarz tlenu (Second face of oxygen - in Polish), PWN, Warsaw, 2004.

7. Callahan H.L., Crouch R.K., James E.R.: Helminth antioxidant enzymes: a protective mechanism against host oxidants. Parasitol Today, 1988, 4, 218-225, doi: 10.1016/0169-4758(88)90162-7.

8. Chaudhuri S., Varshney J.P., Patra R.C.: Erythrocytic antioxidant defence, lipid peroxides level and blood iron, zinc and copper concentrations in dogs naturally infected with Babesia gibsoni. Res Vet Sci 2008, 85, 120-124, doi: 10.1016/j.rvsc.2007.09.001.

9. Corrigall W., Dalgarno A.C., Ewen L.A., Williams R.B.: Modulation of plasma copper and zinc concentrations by disease status in ruminants. Vet Rec 1976, 99, 396-397, doi: 10.1136/vr.99.20.396.

10. Costa-Júnior L.M., Ribeiro M.F., Rembeck K., Rabelo E.M., Zahler-Rinder M., Hirzmann J., Pfister K., Passos L.M.: Canine babesiosis caused by Babesia canis vogeli in rural areas of the State of Minas Gerais, Brazil and factors associated with its seroprevalence. Res Vet Sci 2009, 86, 257-260, doi: 10.1016/j.rvsc.2008.07.002.

11. Crnogaj M., Cerón J.J., Šmit I., Kiš I,., Gotić J., Brkljačić M., Matijatko V., Rubio C.P., Kučer N., Mrljak V.: Relation of antioxidant status at admission and disease severity and outcome 
in dogs naturally infected with Babesia canis canis. BMC Vet Res 2017, 13, 114, doi: 10.1186/s12917-017-1020-9.

12. Crnogaj M., Petlevski R., Mrljak V., Kiš I., Torti M., Kučer N., Matijatko V., Sacer I., Stokovic I.: Malondialdehyde levels in serum of dogs infected with Babesia canis. Vet Med 2010, 55, 163-171, doi: 10.17221/77/2010-vetmed.

13. D’Souza B., D'Souza V., Swagata H., Vijayalaxmi K., Namratha A.S.: Erythrocyte antioxidant enzymes and their correlation with malondialdehyde in malaria. Biomed Res 2009, 20, 25-27.

14. Esmaeilnejad B., Tavassoli M., Asri-Rezaei S., Dalir-Naghadeh B., Malekinejad H., Jalilzadeh-Amin G., Arjmand J., Golabi M., Hajipour N.: Evaluation of antioxidant status, oxidative stress and serum trace mineral levels associated with Babesia ovis parasitemia in sheep. Vet Parasitol 2014, 205, 38-45, doi: 10.1016/j.vetpar.2014.07.005.

15. Evans P., Halliwell B.: Micronutrients: oxidant/antioxidant status. Br J Nutr 2001, 85(S2), S57-S74, doi: 10.1049/BJN2000296.

16. Halliwell B.: Free radicals and antioxidants: a personal view. Nutr Rev 1994, 52, 253-265, doi: 10.1111/j.1753-4887.1994. tb01453.x.

17. Irwin P. J.: Canine babesiosis: from molecular taxonomy to control. Parasit Vectors 2009, 2(S1), S4, doi: 10.1186/1756-33052-S1-S4.

18. Kjemtrup A.M., Wainwright K., Miller M., Penzhorn B.L., Carreno R.A.: Babesia conradae, sp. nov., a small canine Babesia identified in California. Vet Parasitol 2006, 138, 103-111, doi: 10.1016/j.vetpar.2006.01.044.

19. Kumar R., Malik J.K.: Influence of experimentally induced theileriosis (Theileria annulata) on the pharmacokinetics of a long acting formulation of oxytetracycline (OTC-LA) in calves. J Vet Pharmacol Ther 1999, 22, 320-326, doi: 10.1046/j.13652885.1999.00227.x.

20. Kumar S.P., Setty D.R.L., Yathiraj S., Kamalapur P.N.: Use of levamisole along with oxytetracycline and supportive therapy for the treatment of theileriosis in cattle. Indian Vet J 1988, 65, 634-637.

21. Mierzejewska E.J., Dwużnik D., Koczwarska J., Stańczak Ł., Opalińska P., Krokowska-Paluszak M., Wierzbicka A., Górecki G., Bajer A.: The red fox (Vulpes vulpes), a possible reservoir of Babesia vulpes, B. canis and Hepatozoon canis and its association with the tick Dermacentor reticulatus occurrence. Ticks Tick Borne Dis 2021, 12, 101551, doi: 10.1016/j.ttbdis.2020.101551.

22. Müller S., Liebau E., Walter R.D., Krauth-Siegel R.L.: Thiol-based redox metabolism of protozoan parasites. Trends Parasitol 2003, 19, 320-328, doi: 10.1016/S1471-4922(03)00141-7.
23. Murase T., Ueda T., Yamato O., Tajima M., Maede Y.: Oxidative damage and enhanced erythrophagocytosis in canine erythrocytes infected with Babesia gibsoni. J Vet Med Sci 1996, 58, 259-261, doi: 10.1292/jvms.58.259.

24. Oteiza P.I., Olin K.L., Fraga C.G., Keen C.L.: Zinc deficiency causes oxidative damage to proteins, lipids and DNA in rat testes. J Nutr 1995, 125, 823-829, doi: 10.1093/jn/125.4.823.

25. Otsuka Y., Yamasaki M., Yamato O., Maede Y.: Increased generation of superoxide in erythrocytes infected with Babesia gibsoni. J Vet Med Sci 2001, 63, 1077-1081, doi: 10.1292/jvms.63.1077.

26. Razavi S.M., Nazifi S., Bateni M., Rakhshandehroo E.: Alterations of erythrocyte antioxidant mechanisms: antioxidant enzymes, lipid peroxidation and serum trace elements associated with anemia in bovine tropical theileriosis. Vet Parasitol 2011, 180, 209-214, doi: 10.1016/j.vetpar.2011.03.011.

27. Reyers F., Leisewitz A.L., Lobetti R.G., Milner R.J., Jacobson L.S., van Zyl M.: Canine babesiosis in South Africa: more than one disease. Does this serve as a model for falciparum malaria? Ann Trop Med Parasitol 1998, 92, 503-511, doi: 10.1080/00034983. 1998.11813308

28. Schetters T.P., Kleuskens J., Scholtes N., Gorenflot A.: Parasite localization and dissemination in the Babesia-infected host. Ann Trop Med Parasitol 1998, 92, 513-519, doi: 10.1080/00034983.1998.11813309.

29. Schetters T.P., Moubri K., Cooke B.M.: Comparison of Babesia rossi and Babesia canis isolates with emphasis on effects of vaccination with soluble parasite antigens: a review. J S Afr Vet Assoc 2009, 80, 75-78, doi: 10.4102/jsava.v80i2.174.

30. Thorburn D.R., Beutler E.: Chapter 2, The loss of enzyme activity from erythroid cells during maturation. In: Red Blood Cell Aging. Volume 307 of the Advances in Experimental Medicine and Biology series, edited by M. Magnani, A De Flora, Plenum Press, New York, 1991, pp. 15-27, doi: 10.1007/978-1-4684-5985-22.

31. Wegner T.N., Ray D.E., Lox C.D., Stott G.H.: Effect of stress on serum zinc and plasma corticoid in dairy cattle. J Dairy Sci 1973, 56, 748-752, doi: 10.3168/jds.S0022-0302(73)85245-2.

32. Yamasaki M., Otsuka Y., Yamato O., Tajima M., Maede Y.: The cause of the predilection of Babesia gibsoni for reticulocytes. J Vet Med Sci 2000, 62, 737-741, doi: 10.1292/jvms.62.737.

33. Zahler M., Schein E., Rinder H., Gothe R.: Characteristic genotypes discriminate between Babesia canis isolates of differing vector specificity and pathogenicity to dogs. Parasitol Res 1998, 84, 544-548, doi: 10.1007/s004360050445. 